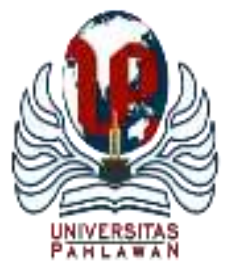

Edukatif : Jurnal Ilmu Pendidikan Volume 3 Nomor 6 Tahun 2021 Halm 5101 - 5108

EDUKATIF: JURNAL ILMU PENDIDIKAN

Research \& Learning in Education

https:/ledukatif.org/index.php/edukatif/index

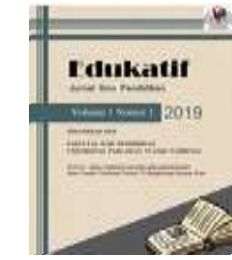

\title{
Peran Guru Bimbingan dan Konseling dalam Meningkatkan Motivasi Belajar Siswa di Era COVID-19 (Studi Literatur)
}

\author{
Rasmi Sitanggang ${ }^{凶}$ \\ SMP Negeri 1 Hiliserangkai, Indonesia \\ E-mail : rasmisitanggang50@ gmail.com
}

\begin{abstract}
Abstrak
Pembelajaran online atau jarak ajuh ini banyak menimbulkan banyak masalah yang salah satunya yaitu penurunan motivasi belajar pada siswa. Penelitian ini menggunakan penelitian kepustakaan, dimana pengumpulan datanya berasal berbagai jurnal maupun buku yang dianalisis sesuai dengan masalah yang ada. Hasil penelitian ini menunjukkan bahwa peran guru bimbingan dan konseling dalam meningkatkan motivasi belajar siswa di era covid19 Guru BK sebagai konselor sekaligus informator, motivator, direktor, dan transmitter bertugas untuk mengembangkan potensi dan memandirikan konseli dalam pengambilan keputusan dan pilihan untuk mewujudkan kehidupan yang produktif, sejahtera, dan peduli kemaslahatan umum. Peran guru bimbingan dan konseling dalam meningkatkan motivasi belajar yaitu dilakukan dengan layanan informasi dan metode home visit. Faktor penghambat yang dihadapi oleh para pengajar Bimbingan Konseling di sekolah adalah bahwa siswa biasanya tidak memiliki keinginan untuk terbuka tentang sekolah, yang membutuhkan lebih banyak pendekatan dan menjadi kendala karena saat ini dimasa pandemi kegiatan belajar mengajar dilakukan secara daring atau dari rumah masing-masing. Jadi yang memiliki peranan penting saat ini bukan hanya guru melainkan wali murid (orang tua siswa). Faktor penghambat yang berkaitan dengan orang tua siswa. Serta terdapat faktor hambatan peranan guru bimbingan dan konseling yaitu kurangnya fasilitas sarana dan prasarana untuk belajar secara daring.
\end{abstract}

Kata Kunci: Guru Bimbingan dan Konseling, Motivasi Belajar, Covid-19

\begin{abstract}
Online or distance learning causes many problems, one of which is a decrease in students' learning motivation. This study uses library research, where the data collection comes from various journals and books which are analyzed according to the existing problems. The results of this study indicate that the role of guidance and counseling teachers in increasing student learning motivation in the covid-19 era BK teachers as counselors as well as informers, motivators, directors, and transmitters are tasked with developing potential and making counselees independent in making decisions and choices to create a productive life. , prosperous, and care for the public good. The role of guidance and counseling teachers in increasing learning motivation is done by using information services and home visit methods. The inhibiting factor faced by Guidance Counseling teachers at schools is that students usually do not have the desire to be open about schools, which requires more approaches and becomes an obstacle because currently during the pandemic teaching and learning activities are carried out online or from their respective homes. So, the one who has an important role at this time is not only the teacher but the student's guardian (parents). Inhibiting factors related to students' parents. And there are factors that hinder the role of guidance and counseling teachers, namely the lack of facilities and infrastructure for online learning.
\end{abstract}

Keywords: Counseling Teachers, Learning Motivation, Covid-19

Copyright (c) 2021 Rasmi Sitanggang

$\triangle$ Corresponding author:

Email : rasmisitanggang50@gmail.com

DOI : https://doi.org/10.31004/edukatif.v3i6.1647

ISSN 2656-8063 (Media Cetak)

ISSN 2656-8071 (Media Online)

Edukatif : Jurnal Ilmu Pendidikan Vol 3 No 6 Tahun 2021 p-ISSN 2656-8063 e-ISSN 2656-8071 
5102 Peran Guru Bimbingan dan Konseling dalam Meningkatkan Motivasi Belajar Siswa di Era COVID-19 (Studi Literatur) - Rasmi Sitanggang

DOI: https://doi.org/10.31004/edukatif.v3i6.1647

\section{PENDAHULUAN}

Coronavirus adalah jenis virus baru yang awalnya muncul di Kota Wuhan, Wilayah Hubei, Cina pada tahun 2019, namanya "Penyakit Covid 2019" yang juga disebut Coronavirus (Anggyanna, 2018). Coronavirus ini membuat pandemi yang berlangsung hari ini di berbagai negara di seluruh planet ini. Efek samping virus corona yang dialami pasien virus corona antara lain batuk kering, sesak napas hingga demam $38^{\circ} \mathrm{C}$ hingga dapat berakibat pada kematian. Wabah virus corona juga terjadi di Indonesia. Per 30 Agustus 2020 tercatat Indonesia memiliki 172.053 kasus positif, dimana 7.343 orang meninggal dan 40.525 orang menjalani pengobatan (Kemendikbud, 2020).

Coronavirus berdampak pada semua bagian kehidupan, termasuk pada dunia pendidikan. Pengaruh pandemi Coronavirus pada Pendidikan yaitu seperti sekolah, sekolah agama, universitas dan pesantren. UNESCO menunjukkan bahwa per 13 April 191 negara telah melakukan antisipasi melalui pemutusan hubungan sekolah lintas negara yang dinilai sekitar 1.575.270.054 siswa (91,3\% dari jumlah siswa terbanyak di dunia)(UNESCO, 2020).

Dinas Pendidikan dan Kebudayaan (Kemendikbud) saat ini telah membuat peraturan untuk menangani penyebaran pandemi virus corona (Pusdiklat Kemdikbud, 2020). Dinas Pendidikan dan Kebudayaan Republik Indonesia (Mendikbud RI) membuat strategi penurunan komunikasi yang sebenarnya dengan mengarahkan Pembelajaran Jarak Jauh (PJJ). Pembelajaran Jarak Jauh mengandung pengertian bahwa proses mendidik dan menerima dilakukan dari rumah atau tidak dilakukan di sekolah secara bertatap muka langsung. Dalam penerapannya, PJJ memiliki beberapa keunggulan. PJJ membuat pembelajaran tersedia dari mana saja dan kapan saja (Shukla, T., Dosaya, D., Nirban, V. S., \& Vavilala, 2020). Pemanfaatan media web dalam adaptasi jarak jauh juga memungkinkan siswa lebih mudah beradaptasi dalam mencari data (Hastini, L. Y., Fahmi, R., \& Lukito, 2020a).

Berbagai permasalahan pembelajaran yang berbeda juga ditemukan selama proses pembelajaran jarak jauh. Masalah yang ditemukan adalah masalah jaringan web yang ditemukan di wilayah tertentu (Hastini, L. Y., Fahmi, R., \& Lukito, 2020b). Kemudian terdapat juga masalah lainnya yaitu kebutuhan akan kuota internet yang berdampak terhadap pengeluaran bagi siswa dengan kuangan yang sulit (Morgan, 2020). Dengan permasalahan yang digambarkan di atas, keberhasilan pelaksanaan pembelajaran jarak jauh bergantung pada kesiapan sekolah secara keseluruhan dan instruktur secara khusus (Kurnianingsih, 2017). Hal serupa juga ditemukan dalam penemuan jarak jauh bahwa tidak semua instruktur idealnya dapat menyelesaikan proses pendidikan dan pembelajaran (Morgan, 2020).

Menurut Chaterine, (2020), banyaknya pengajar yang memberikan tugas kepada siswa menyebabkan sebagian besar siswa merasa putus asa dan gelisah. Hal ini sesuai dengan penilaian Raharjo dan Sari, 2020, bahwa usaha yang diberikan oleh pendidik dengan waktu penanganan yang singkat sangat merepotkan siswa dan mengacaukan sistem pembelajaran pengaturan. Siswa secara teratur menghabiskan seluruh energi mereka dari pagi hingga malam hanya untuk menyelesaikan berbagai tugas berbasis web. Demikian pula dengan hasil ikhtisar KPAI pada 13 April hingga 27 April 2020 terhadap 1.700 responden siswa SD hingga SMP di 20 wilayah.

Dalam rangka untuk mencegah akibat buruk yang mungkin timbul karena masalah belajar yang dialami siswa selama kurun waktu Coronavirus, pengajar (Wali dan Pendidik, Pengajar dan Pembimbing) harus mengetahui tentang efek samping dari kesulitan belajar yang mungkin dapat dialami oleh siswanya. Untuk situasi ini, organisasi atau sekolah, khususnya sekolah memiliki tanggung jawab besar dalam membantu siswa agar mereka bisa menang dalam hal belajar di masa virus corona ini. Sekolah harus memberikan bantuan kepada siswa untuk mengatasi masalah yang muncul dalam latihan pembelajaran jarak jauh (Cahyanto et al., 2021). Oleh karena itu, salah satu komponen yang harus diciptakan adalah faktor interior, menjadi inspirasi belajar mahasiswa khusus selama masa COVID19 (Agustina, 2018). 
5103 Peran Guru Bimbingan dan Konseling dalam Meningkatkan Motivasi Belajar Siswa di Era COVID-19 (Studi Literatur) - Rasmi Sitanggang

DOI: https://doi.org/10.31004/edukatif.v3i6.1647

Berdasarkan penjelasan di atas, para ahli tertarik untuk mengarahkan penelitian pada siswa yang memiliki masalah belajar, terutama masalah inspirasi belajar siswa yang tidak ideal dan tugas mengarahkan dan menasihati para pendidik dalam membantu siswa dengan mengatasi masalah inspirasi siswa di Coronavirus. Asosiasi aktual dengan memimpin Pembelajaran Jarak Jauh (PJJ). Pembelajaran Jarak Jauh mengandung pengertian bahwa proses pengajaran dan pengambilan dalam dilakukan dari rumah atau tidak dilakukan di sekolah secara langsung. Dalam penerapannya, PJJ memiliki beberapa keunggulan. PJJ membuat pengajaran dan latihan terbuka dari mana saja dan kapan saja (Shukla, T., Dosaya, D., Nirban, V. S., \& Vavilala, 2020). Pemanfaatan media web dalam adaptasi jarak jauh juga memungkinkan siswa lebih mudah beradaptasi dalam mencari data (Hastini, L. Y., Fahmi, R., \& Lukito, 2020a)

Masalah pembelajaran yang berbeda juga ditemukan selama proses pembelajaran jarak jauh. Masalah yang ditemukan adalah masalah jaringan web ditemukan di wilayah tertentu (Hastini, L. Y., Fahmi, R., \& Lukito, 2020a). Kemudian lagi, persyaratan jumlah web mempengaruhi pencarian siswa dengan akun bermasalah (Morgan, 2020). Dengan permasalahan yang digambarkan di atas, keberhasilan pelaksanaan pembelajaran jarak jauh bergantung pada kesiapan sekolah secara keseluruhan dan pendidik secara khusus (Rusdiana, E., \& Nugroho, 2020). Hal serupa juga ditemukan dalam penemuan jarak jauh bahwa tidak semua pendidik idealnya dapat menyelesaikan proses pengajaran dan pembelajaran (Morgan, 2020).

Berdasarkan penjelasan di atas, betapa pentingnya motivasi belajar bagi siswa. Motivasi belajar yang telah ada wajib di tingkatkan dan siswa yang belum memiliki motivasi belajar diharapkan untuk berusaha untuk menumbuhkan motivasi belajar tersebut. Sehingga tujuan yang ingin dicapai berjalan dengan optimal. Penelitian ini memiliki manfaat memberikan pemahaman terhadap peran guru bimbingan dan konseling dalam meningkatkan motivasi belajar siswa serta factor-faktor yang menghambat peran guru bimbingan dan konseling dalam meningkatkan motivasi belajar.

\section{METODE PENELITIAN}

Jenis penelitian ini yaitu studi literatur, dimana pengumpulan datanya berasal berbagai jurnal maupun buku yang dianalisis sesuai dengan masalah yang ada. Pencarian jurnal maupun buku dengan online melalui repositori berbagai jurnal yang sudah terbit di berbagai web.

Sumber data yang digunakan yaitu data sekunder yang tidak berasal dari pengamatan langsung, melainkan dari hasil penelitian yang dilaksanakan oleh peneliti sebelumnya. Data ini dihasilkan dengan mencari berbagai referensi tentang subjek penelitian, yang kemudian disajikan dalam bentuk deskripsi (Ernaliana, E., \& Rasidi, 2021). Metode pengumpulan data dilakukan dalam pencarian ataupun menggali sebuah data dari kepustakaan yang berkaitan dalam permasalahan yang ada. Setelah, data diperoleh maka data tersebut dikumpulkan hingga menjadi dokumen yang dapat digunakan.

\section{HASIL DAN PEMBAHASAN PENELITIAN}

Pada era pandemi Covid-19 saat ini banyak beberapa bidang ekonomi, Pendidikan, sosial yang terdampak. Salah satu bidang yang paling terdampak yaitu di bidang Pendidikan. Sekolah memiliki tata cara tersendiri agar tidak terjadi penularan infeksi virus Corona, khususnya yang dilakukan oleh pemerintah yaitu melakukan Pembelajaran Jarak jauh atau boleh disingkat PJJ. Dalam penerapannya, PJJ menikmati beberapa manfaat. PJJ membuat pengajaran dan latihan terbuka dari mana saja (Shukla, T., Dosaya, D., Nirban, V. S., \& Vavilala, 2020). Pemanfaatan media web dalam adaptasi jarak jauh juga memungkinkan siswa lebih mudah beradaptasi dalam mencari data (Hastini, L. Y., Fahmi, R., \& Lukito, 2020b).

\section{Motivasi Belajar Siswa}

Menurut riyanti, (2019) motivasi adalah upaya untuk mempengaruhi individu yang dipimpinnya untuk mencapai pekerjaan yang dia inginkan sesuai dengan tujuan tertentu yang telah diberikan sebelumnya. Motivasi sangat penting dalam pembelajaran dengan alasan bahwa adanya motivasi akan mendukung 
5104 Peran Guru Bimbingan dan Konseling dalam Meningkatkan Motivasi Belajar Siswa di Era COVID-19 (Studi Literatur) - Rasmi Sitanggang

DOI: https://doi.org/10.31004/edukatif.v3i6.1647

seseorang untuk terus belajar dan sebaliknya ketiadaan motivasi akan melemahkan sikap seseorang untuk belajar (Tawaningsih, 2016). Menurut Resti RIYANTI, (2019) seseorang yang tidak memiliki motivasi, biasanya siswa yang sering bermain-main pada jam sekolah, siswa yang sering tidak menyelesaikan pekerjaan dan siswa yang tidak fokus pada guru selama sistem pembelajaran.

Pemberian layanan informasi yang diberikan guru BK untuk membangun motivasi belajar siswa dalam pembelajaran agar dilakukan dengan tepat. Hal ini dibuktikan dengan berkembangnya kesadaran motivasi BK terhadap rendahnya motivasi siswa, maka para guru BK dan kepala sekolah bekerja sama dalam menangani masalah ini. Dalam menangani masalah ini, kepala sekolah memberikan kepercayaan penuh kepada guru BK. Berdasarkan pemaparan guru BK dan kepala sekolah, sejauh ini penanganan siswa dengan motivasi belajar rendah sudah dilakukan dengan baik oleh guru BK melalui layanan informasi.

Menurut Tawaningsih, (2016) ada empat kapasitas dalam mengikuti dan meningkatkan pembelajaran siswa, yaitu: (1) menggairahkan siswa, khususnya mengikuti minat siswa dengan memberikan kesempatan khusus untuk bergerak mulai dari satu sudut pandang kemudian ke bagian selanjutnya. pembelajaran dalam situasi belajar, (2) memberikan asumsi yang masuk akal, Arahan dan saran pendidik harus mengikuti asumsi siswa yang masuk akal dan menyesuaikan asumsi yang kurang atau konyol, selanjutnya informasi yang memadai diperlukan sehubungan dengan prestasi atau kekecewaan siswa sebelumnya, (3) memberikan motivasi, jika siswa unggul Dalam hal pembelajaran, guru pembimbing dan pembimbing diandalkan untuk memberikan hadiah kepada siswa (bisa berupa pujian, angka yang diterima, dll), sehingga anak-anak akan semakin terdorong untuk melakukan upaya lebih lanjut untuk berprestasi. tujuan pembelajaran, (4) mengarahkan siswa melakukan, Mengarahkan dan membimbing Guru BK yang diperlukan untuk bereaksi terhadap siswa yang tidak terlibat secara langsung dalam pembelajaran di kelas secara daring.

Cara mengkoordinasikan perilaku siswa adalah dengan memberikan tugas, mendekatkan diri, memberikan disiplin yang mendidik, mencela dengan mental yang halus dan dengan kata-kata yang baik dan bijaksana. Mengingat hasil eksplorasi menunjukkan rendahnya hubungan tugas mengarahkan dan menasihati pendidik dengan inspirasi belajar siswa, untuk memperluas inspirasi motivasi belajar siswa melalui tugas mengarahkan dan membimbing instruktur penting untuk memperhatikan sudut pandang Sukmadinata dalam (Nafisah, Jarkawi, 2021) Beberapa upaya yang dapat dilakukan oleh guru dalam meyakinkan pembelajaran adalah sebagai berikut: (1) pembimbing dapat memberikan data, klarifikasi disertai dengan contoh-contoh pentingnya pembelajaran, kemajuan yang dapat dicapai dengan memeriksa, individu efektif mengingat fakta bahwa mereka konstan dan berkonsentrasi keras, (b) terhadap kelas, kelompok atau siswa individu yang mendominasi diberikan pujian, penghargaan atau hadiah. Untuk menghasilkan inspirasi belajar secara mendasar, pembimbing dapat melakukannya melalui pemberian pujian (Mumpuni, 2021). Pengakuan akan membangkitkan energi, namun sekali lagi analisis, celaan, dan kemarahan akan membunuh inspirasi untuk belajar, dan (c) penghargaan terhadap karakter anak. Semua orang, termasuk anak-anak dan remaja, perlu diakui dan dihargai. Upaya untuk menciptakan inspirasi belajar harus didasarkan pada sikap yang bijaksana dan pengakuan dari instruktur terhadap kehadiran dan karakter siswa. Dengan arahan yang baik dan metodis, siswa yang mengalami kendala dalam motivasi belajar akan mendapat dukungan dan berbuah dalam ujiannya (Imroatul \& Muhid, 2021).

Upaya yang dilakukan guru BK dalam mengarahkan dan membimbing dalam membujuk siswa yang membutuhkan inspirasi antara lain: (a) memberikan penghiburan kepada siswa agar terdorong dalam belajar dan mengenalkan siswa untuk mengkaji penilaian atau tujuan individu mereka, untuk membentengi inspirasi dalam diri mereka. siswa, (b) mengarahkan dan menasihati pendidik, memberikan bimbingan tentang minat siswa agar mereka dapat meningkatkan belajarnya dan memahami dengan tegas dan kuat serta dapat dengan mudah memutuskan, mengkoordinasikan dan mengakui diri mereka sendiri dengan bangga dan akan bermanfaat sesuai dengan pekerjaan yang mereka butuhkan di kemudian hari, ( c) Pembimbing membantu pengajar mata pelajaran dan wali siswa yang sangat diharapkan agar siswa mendapatkan bantuan penuh 
5105 Peran Guru Bimbingan dan Konseling dalam Meningkatkan Motivasi Belajar Siswa di Era COVID-19 (Studi Literatur) - Rasmi Sitanggang

DOI: https://doi.org/10.31004/edukatif.v3i6.1647

dengan tujuan agar mereka tergugah untuk lebih mengembangkan hasil belajarnya, dan (d) kerangka kerja diperlukan untuk membantu pembelajaran Oleh karena itu, kantor dan perlengkapan kantor di sekolah harus disiapkan (Baidlowi, 2019).

Dapat disimpulkan bahwa motivasi untuk belajar siswa sangat penting untuk mendukung agar siswa terus belajar dan guru memiliki peranan untuk meningkatkan motivasi belajar siswa. Salah satunya yaitu guru BK. Cara yang digunakan guru BK dalam meningkatkan motivasi belajar siswa yaitu dengan melakukan pemberian layanan informasi kepada siswa. Terdapat juga berbagai cara yang dapat dilakukan guru BK dalam meningkatkan motivasi siswa diantaranya dapat menggairahkan siswa dalam belajar dengan mengikuti minat, memberikan arahan yang mudah di pahami dan dilakukan oleh siswa, memberikan motivasi seperti contohnya memberikan hadiah dan mengarahkan siswa agar mempraktekan atau dapat juga ikut aktif dalam proses belajar. Serta dapat juga memberikan hiburan untuk siswa, memberikan arahan dan nasihat kepada pendidik, melakukan bimbingan kepada guru dan wali murid agar dapat memberikan bantuan kepada siswa untuk meningkatkan motivasi siswa dalam belajar, membuat kerangka kerja untuk membantu pembelajaran.

\section{Peran Guru Bimbingan dan Konseling dalam Meningkatkan Motivasi Belajar}

Pernyataan dari para ahli, dapat diartikan bahwa pengajar BK mengetahui motivasi belajar siswa masih rendah, namun guru BK telah mengambil langkah dalam hal ini dengan terus membangun motivasi siswa melalui data.layanan informasi (Anggyanna, 2018). Layanan informasi yang di berikan akan diberikan oleh para guru BK di setiap kelas binaannya, hal ini merupakan temuan untuk membangun motivasi siswa dengan memberikan pengaturan waktu belajar dan penghiburan dalam belajar dan sebagai upaya preventif bagi siswa yang masih belum memiliki motivasi belajar (Baidlowi, 2019).

Peneliti simpulkan bahwa guru BK secara rutin menawarkan jenis bantuan kepada siswa, baik itu belajar bersama atau kursus yang sering mereka berikan ketika siswa menghadapi UN atau di mana mereka akan mengikuti kelulusan, para pendidik BK secara konsisten memberikan data ini kepada siswa, jadi Siswa lebih banyak berusaha untuk mencapai apa yang mereka butuhkan (Ibrahim, 2019). Guru BK juga melakukan yang namanya tutor sebaya dan fasilitas belajar serta bekerjasama dengan pengajar mata pelajaran untuk membantu siswa yang mengalami kesulitan belajar dengan adanya pusat pembelajaran dan pendampingan teman, siswa melihat lebih banyak apa yang belum mereka pahami dan pahami (Setiadi et al., 2020) . Menurut Muslih \& Harini, (2015) mengungkapkan bahwa peran Guru BK sebagai konselor sekaligus informator, motivator, director, dan transmitter bertugas untuk mengembangkan potensi dan memandirikan konseli dalam pengambilan keputusan dan pilihan untuk mewujudkan kehidupan yang produktif, sejahtera, dan peduli kemaslahatan umum. Peran guru BK yang dapat dilakukan yaitu menggunakan metode home visit. Menurut Handayani dalam (Fadillah Ulva, 2021) yang mengungkapkan bahwa metode home visit yaitu dilakukan guru BK mengunjungi rumah siswa untuk memantau bagaimana proses belajar siswa.

Peran guru bimbingan dan konseling dalam meningkatkan motivasi belajar yaitu dilakukan dengan layanan informasi. Maksud dari layanan informasi ini merupakan informasi terkait pemahaman yang berhubungan dengan siswa. Contohnya yaitu siswa kurang memahami tentang pelajaran Biologi atau siswa kurang memahami apa yang di terangkan oleh guru ketika belajar daring. hal ini dapat memberikan gambaran kepada guru agar mengevaluasi cara mengajar. Berdasarkan keterangan yang telah dipaparkan terlihat bahwa, alasan guru BK dalam memilih dan memberikan layanan informasi untuk meningkatkan motivasi berprestasi siswa tidaklah keliru. Layanan informasi memang berfungsi sebagai pemberian pemahaman, yaitu pemahaman siswa terhadap diri sendiri, lingkungan sekolah, keluarga dan masyarakat agar siswa terhindar dari permasalahan yang mungkin dapat menghambatnya dalam berkembang. Disamping itu layanan informasi juga berfungsi sebagai pencegahan terhadap permasalahan yang di alami siswa secara umum, agar tercegahnya atau terhindarnya siswa dari permasalahan yang mungkin timbul yang akan dapat mengganggu, menghambat ataupun menimbulkan kesulitan dan kerugian tertentu dalam proses perkembangannya. Guru BK 
5106 Peran Guru Bimbingan dan Konseling dalam Meningkatkan Motivasi Belajar Siswa di Era COVID-19 (Studi Literatur) - Rasmi Sitanggang

DOI: https://doi.org/10.31004/edukatif.v3i6.1647

juga sering melakukan cara-cara lain untuk meningkatkan motivasi yaitu dengan rutin menawarkan jenis bantuan kepada siswa seperti contohnya bimbingan belajar.

\section{Faktor Penghambat Peranan Guru Bimbingan dan Konseling}

Faktor penghambat membatasi peranan guru bimbingan dan konseling untuk meningkatkan motivasi belajar siswa berhubungan dengan adanya sarana dan prasarana pendidikan. Pada penerapan pembelajaran dari rumah ini pasti fasilitas yang sangat diperlukan merupakan adanya handphone untuk sebagai alat dalam proses pembelajaran jauh antara guru dengan seluruh siswa. Fasilitas serta prasarana pendidikan mempunyai hubungan yang signifikan dalam menumbuhkan motivasi belajar siswa, apabila fasilitas sarana bertambah, sehingga sebaiknya diimbangi pula dengan meningkatnya motivasi belajar siswa (Arianti, 2019). Penelitian ini selajan dengan penelitian yang dilakukan oleh (Nanda, 2021) yang mengungkapkan masih banyak siswa yang masih belum memiliki fasilitas seperti handphone sendiri melainkan masih bergabung dengan orang tua.

Menurut Retno Kristiawati dalam Nafisah, Jarkawi, (2021) dari hasil data tidak terdapat siswa yang memanfaatkan layanan BK dengan baik dan terdapat juga siswa yang tidak dapat memanfaatkan layanan dengan baik. Menurut aliwanto dalam Nafisah, Jarkawi, (2021) dalam pelaksanaan bimbingan dan konseling menggunakan humanistik memiliki faktor penghambat karena sulit di dalam pelaksanaan bimbingan dan nasehat menggunakan humanistik memiliki unsur represif karena sulit diterapkan pada siswa yang tidak dapat diberikan layanan. Faktor penghambat yang dihadapi oleh para pengajar Bimbingan Konseling di sekolah adalah bahwa siswa biasanya tidak memiliki keinginan untuk terbuka tentang sekolah, yang membutuhkan lebih banyak pendekatan dan menjadi kendala karena saat ini dimasa pandemi kegiatan belajar mengajar dilakukan secara daring atau dari rumah masing-masing. Jadi yang memiliki peranan penting saat ini bukan hanya guru melainkan wali murid (orang tua siswa). Faktor penghambat yang berkaitan dengan orang tua siswa.

Orangtua adalah salah satu aspek dari lingkungan sekitar bisa pengaruhi perhatian belajar, dorongan dari orangtua dapat berbentuk dorongan emosi yaitu keperdulian, atensi, dan motivasi, dorongan penghargaan (dorongan bersifat positif ataupun pemberian penghargaan), dorongan instrumental (bayaran serta sarana belajar), dan dukungan data (arahan, anjuran, nasihat). Tidak hanya tersebut, atensi yang diberikan orang tua terhadap anak bisa menumbuhkan motivasi belajar individu pada saat mengerjakan tugas sekolahnya (Jamko, 2015). Penelitian ini juga didukung oleh penelitian yang dilakukan oleh Syaiful, (2020) yang menyatakan bahwa orang tua sangat berpengaruh terhadap perkembangan belajar siswa. Orang tua sangat membantu guru agar orang tua dan guru saling bekerja sama dalam meningkatkan motivasi belajar siswa. Tetapi orang tua masih kurang perhatian terhadap belajar anaknya dan masih banyak orang tua yang menganggap saat ini masih libur sekolah.

Terlebih apabila pada peraturan ini pendidikan di sekolah ditukar dengan adanya pemberian tugas dirumah. Orangtua saat pandemi virus covid - 19 mempunyai hubungan yang signifikan terhadap individu pada saat melaksanakan proses pembelajaran siswa, entah secara struktur, pembagian tugas sebagian peraturan (Syaiful, 2020). Berdasarkan uraian tersebut membuktikan bagimana pentingnya kedudukan guru BK dan orangtua dalam penerapan sekolah dirumah pada saat terdapatnya virus covid-19 yang mengharuskan setiap individu untuk melaksanakan seluruh kegiatan di rumah, keharusan belajar untuk siswa yang sedang melakukan proses pembelajaran.

\section{KESIMPULAN}

Peran guru bimbingan dan konseling dalam meningkatkan motivasi belajar siswa di era covid-19 Guru BK sebagai konselor sekaligus informator, motivator, director, dan transmitter bertugas untuk mengembangkan potensi dan memandirikan konseli dalam pengambilan keputusan dan pilihan untuk mewujudkan kehidupan yang produktif, sejahtera, dan peduli kemaslahatan umum. Peran guru bimbingan dan konseling dalam meningkatkan motivasi belajar yaitu dilakukan dengan layanan informasi dan juga terdapat 
5107 Peran Guru Bimbingan dan Konseling dalam Meningkatkan Motivasi Belajar Siswa di Era COVID-19 (Studi Literatur) - Rasmi Sitanggang

DOI: https://doi.org/10.31004/edukatif.v3i6.1647

layanan dengan metode home visit. Serta terdapat faktor hambatan peranan guru bimbingan dan konseling yaitu kurangnya fasilitas sarana dan prasarana untuk belajar secara daring.

\section{DAFTAR PUSTAKA}

Agustina, M. (2018). Peran Guru Bk Dalam Pembinaan Kesiapan Siswa Mengikuti Konseling di MTS Negeri 3 Helvetia Medan. http://Repository.Uinsu.Ac.Id/7464/

Anggyanna, R. (2018). Peran Guru Bimbingan Dan Konseling (Bk) Dalam Memotivasi Belajar Siswa Berprestasi Non Akademik Pada Siswa Jurusan Ips (Studi Di Sma Negeri 6 Malang). In Central Library Of Maulana Malik Ibrahim. Universitas Islam Negeri Maulana Malik Ibrahim.

Arianti, A. (2019). Peranan Guru Dalam Meningkatkan Motivasi Belajar Siswa. Didaktika: Jurnal Kependidikan, 12(2), 117-134. https://Doi.Org/10.30863/Didaktika.V12i2.181

Baidlowi, M. R. (2019). Peranan Konselor Dalam Peningkatkan Motivasi Belajar Siswa Melalui Layanan Informasi Di Madrasah Aliyah Negeri 1 Lampung Tengah. In Institut Agama Islam Negeri (Iain) Metro (Vol. 52, Issue 1). Institut Agama Islam Negeri (Iain) Metro.

Cahyanto, B., Maghfirah, M., \& Hamidah, N. (2021). Implementasi Pembelajaran Daring Di Masa Pandemi Covid-19. At-Thullab : Jurnal Pendidikan Guru Madrasah Ibtidaiyah, 5(1), 32. https://Doi.Org/10.30736/Atl.V5i1.508

Chaterine, R. N. (2020). Siswa Belajar Dari Rumah, Kpai: Anak-Anak Stres Dikasih Banyak Tugas. Detik News. $\quad$ https://News.Detik.Com/Berita/D-4944071/Siswabelajar-Dari-Rumah-Kpai-Anak-Anak-StresDikasihbanyak-Tugas

Ernaliana, E., \& Rasidi, M. A. (2021). Standar Kualitas Pendidikan Dasar Di Nigeria: Studi Kepustakaan. El Midad, 13(1), 41-49.

Fadillah Ulva, M. Y. (2021). Implementasi Metode Home Visit Untuk Meningkatkan Motivasi Belajar Siswa Sd Pada Masa Pandemik Covid-19. Jurnal Abdidas, 1(3), 149-156.

Hastini, L. Y., Fahmi, R., \& Lukito, H. (2020a). Apakah Pembelajaran Menggunakan Teknologi Dapat Meningkatkan Literasi Manusia Pada Generasi Z Di Indonesia? Jurnal Manajemen Informatika (Jamika), 10(1), 12-28.

Hastini, L. Y., Fahmi, R., \& Lukito, H. (2020b). Apakah Pembelajaran Menggunakan Teknologi Dapat Meningkatkan Literasi Manusia Pada Generasi Z Di Indonesia. Manajemen Informatika (Jamika), 1228.

Ibrahim, M. B. (2019). Peran Guru Bk Dalam Meningkatkan Motivasi Belajar Siswa Yang Kecanduan Smartphone Melalui Layanan Bimbingan Kelompok. Jurnal Bki Uin-Su Tahun 2019, 1(1), 1-9. http://Jurnaltarbiyah.Uinsu.Ac.Id/Index.Php/Almursyid/Article/View/603/514

Imroatul, M. \& E., \& Muhid, A. (2021). Strategi Meningkatkan Motivasi Belajar Siswa Selama Pandemi Covid - 19: Literature Review. Jurnal Ilmiah Bimbingan Konseling Undiksha, 12(1), 21-30. https://Doi.Org/10.23887/Xxxxxx-Xx-0000-00

Jamko, M. T. (2015). Pengaruh Pertumbuhan Ekonomi, Infrastruktur, Pengangguran Terhadap Tingkat Kemiskinan Di Kabupaten Maluku Tenggara. Jurnal Biology Science \& Education 2015, 4(1), 74. https://Doi.Org/10.33477/Bs.V4i1.531

Kemendikbud. (2020, May 23). Kemendikbud Terbitkan Pedoman Penyelenggaraan Belajar Dari Rumah. Kementerian Pendidikan Dan Kebudayaan.

https://Www.Kemdikbud.Go.Id/Main/Blog/2020/05/Kemendikbud-Terbitkan-PedomanPenyelenggaraan-Belajar-Dari-Rumah

Morgan, H. (2020). Best Practices For Implementing Remote Learning Duringn A Pandemi. The Clearing House: A Journal Of Educational Strategies, Issues, And Ideas. 10.1080/00098655.2020.1751480. 
5108 Peran Guru Bimbingan dan Konseling dalam Meningkatkan Motivasi Belajar Siswa di Era COVID-19 (Studi Literatur) - Rasmi Sitanggang

DOI: https://doi.org/10.31004/edukatif.v3i6.1647

Mumpuni, S. D. (2021). Peran Guru Bimbingan Dan Konseling Dalam Meningkatkan Motivasi Belajar Peserta Didik Dalam Menghadapi Ujian Nasional Kelas Xi (Studi Kasus Di Sman 2 Kota Tegal). Jurnal Bimbimbingn Dan Konseling Ar-Rahman, 7(1), 25-33.

Muslih, M., \& Harini, S. (2015). Peran Guru Bk Dalam Meningkatkan Motivasi Dan Religiusitas Siswa Terhadap Orientasi Kerja. Hisbah: Jurnal Bimbingan Konseling Dan Dakwah Islam, 12(2), 35-48. https://Doi.Org/10.14421/Hisbah.2015.122-04

Nafisah, Jarkawi, H. M. (2021). Peranan Guru Bimbingan Dan Konseling Dalam Memotivasi Belajar Siswa Sma Negeri 1 Daha Utara Kabupaten Hulu Sungai Selatan Pendahuluan Guru Bimbingan Dan Konseling ( Guru Bk ) Atau Dapat Juga Disebut Sebagai Konselor Sekolah Sebagai Tenaga Pendidik Disekol. Jurnal Mahasiswa Bk An-Nur : Berbeda, Bermakna, Mulia, 7(3). https://Ojs.Uniska-Bjm.Ac.Id/Index.Php/An-Nur

Nanda, F. R. (2021). Peran Guru Dalam Meningkatkan Motivasi Belajar Siswa Pada Pembelajaran Online Melalui Whatsapp Mata Pelajaran Ilmu Pengetahuan Sosial Kelas Viii Mts Hasyim Asy'ari Tawangsari- Gempol [Universitas Islam Negeri Maulana Malik Ibrahim Malang]. https://Emea.Mitsubishielectric.Com/Ar/Products-Solutions/Factory-Automation/Index.Html

Pusdiklat Kemdikbud. (2020). Surat Edaran Mendikbud No 4 Tahun 2020 Tentang Pelaksanaan Kebijakan Pendidikan Dalam Masa Darurat Penyebaran Corona Virus Disease (Covid- 19 ).

Riyanti, R. (2019). Peran Guru Bimbingan Dan Konseling Dalam Meningkatkan Motivasi Belajar Peserta Didik Kelas Vii Mts Masyariqul Anwar Bandar Lampung Tahun Pelajaran 2018/2019 [Universitas Islam Negeri Raden Intan Lampung]. In Uin Raden Intan Lampung (Vol. 52, Issue 1). http://Repository.Radenintan.Ac.Id/7225/1/Skripsi Resti.Pdf

Rusdiana, E., \& Nugroho, A. (2020). Respon Pada Pembelajaran Daring Bagi Mahasiswa Mata Kuliah Pengantar Hukum Indonesia. Integralistik, 31(1), 1-12. https://Journal.Unnes.Ac.Id/Nju/Index.Php/Integralistik/Article/View/21834/

Setiadi, G., M. Sholihun, \& Nurma Yuwita. (2020). Peranan Guru Bimbingan Konseling Dalam Memotivasi Peserta Didik Selama Masa Pandemi Covid-19 Di Sma Darut Taqwa Pasuruan. Al-Isyrof: Jurnal Bimbingan Konseling Islam, 2(2), 89-107. https://Doi.Org/10.51339/Isyrof.V2i2.224

Shukla, T., Dosaya, D., Nirban, V. S., \& Vavilala, M. P. (2020). Factors Extraction Of Effective Teachinglearning In Online And Conventional Classrooms. International Journal Of Information And Education Technology, 10(6), 422-427.

Syaiful, F. F. (2020). Penerapan Analisis Swot Terhadap Strategi Pemasaran Usaha Minuman Kamsia Boba Milik Abdullah Di Tengah Pandemi Covid-19 Di Kabupaten Bangkalan. Jurnal Edukasi Nonformal, 17, 343-359. https://Ummaspul.E-Journal.Id/Jenfol/Article/View/583

Tawaningsih, T. R. Z. (2016). Pengaruh Bimbingan Konseling Dan Motivasi Belajar Terhadap Pilihan Peminatan Siswa Tawaningsih 1), T. Ramli Zakaria 2) 1). 1, 138-153. https://Doi.Org/10.22236/Jppp

Unesco. (2020). Covid-19 Educational Disruption And Response. Unesco.

https://En.Unesco.Org/Covid19/Educationresponse/ 